\title{
Determination of Resistance to Phytophthora infestans on Potato Plants in Field, Laboratory and Greenhouse Conditions
}

\author{
Buddhi P. Sharma ${ }^{1}$, Gregory A. Forbes ${ }^{2}$, Hira K. Manandhar ${ }^{1}$, Sundar M. Shrestha ${ }^{3} \&$ Resham B. Thapa ${ }^{3}$ \\ ${ }^{1}$ Senior Scientists, Nepal Agricultural Research Council, Nepal \\ ${ }^{2}$ Senior Plant Pathologist, International Potato Center (CIP), Beijing, China \\ ${ }^{3}$ Professors, Institute of Agriculture and Animal Science, Tribhuwan University, Nepal \\ Correspondence: Buddhi Prakash Sharma, National Potato Research Programme, Khumaltar, Lalitpur Nepal. Tel: \\ 977-1-984-135-5750. E-mail: bpsharma068@gmail.com
}

Received: January 1, 2013 Accepted: March 11, 2013 Online Published: April 15, 2013

doi:10.5539/jas.v5n5p148 URL: http://dx.doi.org/10.5539/jas.v5n5p148

\begin{abstract}
An experiment was conducted to determine the host resistance of potato against Phytophthora infestans for twenty-five potato genotypes in 2010 and 2011 at Khumaltar, Lalitpur, Nepal using four assays: three for foliage resistance (field, whole-plant and detached leaf) and one for tuber resistance (tuber slice). An isolate of $P$. infestans collected from Lalitpur (LPR-1) was used for inoculation at a concentration of $3 \times 10^{3}$ sporangia $\mathrm{ml}^{-1}$ in all assays. Infected foliage area in the field and whole-plant assays, lesion size on detached leaves, and colony growth on tuber slice were all individually converted to 0-9 interval scale for susceptibility. Field assessment, considering the most robust measure of resistance, was used as benchmark for comparing the other assays. Sixteen of the genotypes had very little disease in the field (scale value $<1$ ) indicating they were probably expressing race-specific resistance, which has historically been short lived. Susceptibility levels measured in the whole-pant assay were highly correlated $(\mathrm{r}=0.90)$ with converted field scale values, although the correlation was lower for the detached leaf assay $(r=0.63)$ and least for tuber-slice assay $(r=0.46)$. Low correlation in the detached leaf assay was assumed to represent lower resolution of the single-cycle assay. Low correlation in the tuber assay may have also reflected genetic differences as foliage and tuber blight resistance are not always correlated. Genotypes with extreme resistance in the field were frequently identified as having partial resistance in the other assays, which could mistakenly be interpreted as more durable field resistance. The consequences for selecting durable resistance are discussed.
\end{abstract}

Keywords: detached leaf, Phytophthora infestans, potato, resistance, susceptibility, tuber slice assay

\section{Introduction}

Potato late blight, caused by the Oomycete pathogen Phytophthora infestans (Mont.) de Bary, is one of the primary problems faced by small-scale potato producers worldwide. In potato, the third largest global food crop after wheat and rice, per year yield losses and fungicide costs in developing countries alone were estimated at over 10 billion Euros (Haverkort, Struik, Visser, \& Jacobsen, 2009). In addition to economic losses, the disease poses a threat for food security, human health and environment (Kromann, Taipe, Perez, \& Forbes, 2009).

In Nepal, potatoes are grown across varying geographic areas ranging from 75 to $4700 \mathrm{~m}$ a s 1 with different planting seasons: November in low lands, September and January (two seasons) in the mid hills and February/March in the high hills. In Nepal, potato is grown on 182,600 ha for the total production of 2,508,044 Mt, with a productivity of $13.74 \mathrm{t} \mathrm{ha}^{-1}$ (MOAC, 2011) and potato contributes $9.4 \%$ of the national agriculture gross domestic product (AGDP) (MOF, 2010). Late blight is one of the major biotic constraints in potato production in Nepal. It has been estimated that monitory loss due to this disease was approximately 104 million US\$ in FY $2009 / 2010$, based on the total production of that year, an estimated $15 \%$ average loss and an average potato price of $176 \mathrm{US} \$$ ton $^{-1}$. In addition, a large amount of money is routinely spent to manage the crop by frequently applying fungicides e.g., 10-15 times per crop in the autumn season in the Kathmandu valley (Sharma, Khatri-Chhetri, Dhital, Khatri-Chhetri, \& Chand, 2007).

One of the most effective and efficient ways to control any plant disease is with host plant resistance.In the case of potato late blight, however, efforts to control the disease with host resistance have been limited by many factors, 
including market preference of susceptible varieties, lack of seed distribution systems to diffuse new varieties and rapid evolution in the pathogen population toward new pathotypes which overcome race-specific resistance. Many cultivars released as resistant have lost their resistance against new pathotypes in the pathogen population. In contrast, resistance in some cultivars has held for longer time (Forbes, 2012). For example, Janakdev (CIP-720123), which is one of the most popular potato varieties in Nepal, has maintained its resistance for many years.

Resistance in potato to $P$. infestans has been previously classified as either vertical (generally absolute and race-specific) or horizontal (partial and effective against all pathogen races) (Van der Plank, 1963). Subsequent research demonstrated that race-specific resistance is governed by major resistance genes ( $\mathrm{R}$ genes) and their interaction with pathogen effectors (Vleeshouwers et al., 2011). This categorization has been questioned because further research into the genetic and mechanistic basis of resistance have demonstrated that in some ways the two resistance types both involve a hypersensitive reaction (Kamoun, Huitema, \& Vleeshouwers, 1999). Furthermore, the majority of research on resistance to $P$. infestans in recent years has focused on the simultaneous use (stacking) of several R genes newly discovered from wild potato species (Tan, Hutten, Visser, \& Eck, 2010). Regardless of genetic and cellular mechanisms underlying resistance, for the purpose of this study, it is important to recognize that resistance phenotypes may be expressed in one of two ways: i) as apparent immunity, with no visible symptoms or with an indication of hypersensitivity, or ii) by varying levels of disease severity. Resistance of the second phenotype would appear to have less risk of being rapidly overcome by pathogen evolution (Forbes, 2012). The partial resistance phenotype is measured by a specific component of disease or a synoptic measure of overall disease severity through the season, such as the area under the disease progress curve (AUDPC). Recently, an interval scale for resistance in potato to P. infestans was proposed by Yuen and Forbes (2009) to quantify susceptibility of the partial phenotypic expression of resistance.

Resistance to tuber blight caused by P. infestans may (Platt, 1998) or may not (Black, 1970; Inglis et al., 1996; Dorrance \& Inglis, 1997; Kirk et al., 2001) be correlated with foliar resistance. Therefore, it is essential to test breeding lines for susceptibility to $P$. infestansin both tubers and foliage (Douches et al., 2002).

The National Potato Research Program (NPRP) of Nepal regularly evaluates potato genotypes in multiple locations for resistance to $P$. infestans in replicated field trials, in which the effect of resistance on the polycyclic development of the disease can be assessed. Resistance can also be evaluated in more convenient and often less expensive monocyclic or oligocyclic green-house or laboratory assays in which one or more epidemic components, such as lesion expansion rate or sporulation, are measured (Dorrance \& Inglis, 1997). This then leads to the question, to what degree do green-house and laboratory evaluations correlate with results obtained in the field?

The purpose of this investigation was two-fold: i) to identify new sources of resistance to $P$. infestans; and ii) to determine the efficiency of two non-field screening methods for foliage blight resistance and one method for tuber blight resistance and compare results from these assays with resistance levels established in the field.

\section{Materials and Methods}

\subsection{Field Assay}

Twenty-five potato genotypes, including one standard susceptible check, were evaluated for resistance to $P$. infestans at Khumaltar (1360 $\mathrm{m}$ a s 1), a location representing the mid-hills agro-climatic conditions. Planting was done during the second week of September, which is the second or "fall" season in this region and the most conducive to disease development. Ten tubers of each potato clone were planted with a spacing of $60 \mathrm{~cm}$ between and $25 \mathrm{~cm}$ within rows, which were $2.5 \mathrm{~m}$ long, giving a plot size of $1.5 \mathrm{~m}^{2}$. Healthy looking tubers of similar physiological age were used. Genotype LBr-40 and KufriJyoti were used in the experiment as resistant and susceptible checks, respectively. Desiree, a susceptible variety, was planted around the border of the experiment plots to increase inoculum pressure of $P$. infestans. Prior to planting, fertilizer (100:100:60 kg N, $\mathrm{P}_{2} \mathrm{O}_{5}, \mathrm{~K}_{2} \mathrm{O} \mathrm{ha}^{-1}$ respectively along with $20 \mathrm{t} \mathrm{ha}^{-1}$ farmyard manure) was applied.Weeding, earthing-up and irrigation were applied two times at 30 and 50 days after planting. No fungicide was applied throughout the crop period.

At 25 DAP, a suspension of $3 \times 10^{3}$ sporangia $\mathrm{ml}^{-1}$ of $P$. infestans isolate LPR-1 was applied to plants using a 0.5 liter plastic atomizer. Disease severity scoring began with the first appearance of symptoms and continued until the susceptible check reached $100 \%$ of foliage area damaged. Scoring of the disease severity was based on a visual estimation of percent foliage damage and was done at 30,41, 54, 60, 69 and 76 DAP. Percent severity values were converted to the area under the disease progress curve (AUDPC) using the midpoint formula (Campbell \& Madden, 1990; Madden \& Hughes, 1995). 


\subsection{Screen House Assay}

The 25 potato genotypes, which were screened under field conditions, were also evaluated in a whole-plant inoculation assay in screen house, where temperatures ranged from 15 to $25^{\circ} \mathrm{C}$ and relative humidity ranged from 75 to 90 percent. When plants were approximately at flowering stage, each plant was covered with a transparent plastic bag from $24 \mathrm{hr}$ before until $48 \mathrm{hr}$ after inoculation to maintain high relative humidity for better initiation of infection. Spray inoculum was prepared using isolate 'LPR-1'. A sporangial suspension was prepared from 5 days old cultures grown in Petri dishes. Five ml of inoculum at $3 \times 10^{3}$ sporangia $\mathrm{ml}^{-1} \mathrm{plant}^{-1}$ were applied to cover all expanded leaves of test plants using $100 \mathrm{ml}$ glass atomizer. Sterile distilled water was applied on the check plants. After establishing infection, the plastic covers were removed and plants were misted three times daily at 10, 14 and $18 \mathrm{hr}$ for 30 days after the plastic bags were removed. Late blight severity was recorded as percent foliage area damaged on each plant at 30 days after inoculation, using the same visual evaluation method as the field.

\subsection{Detached-Leaf Assay}

Plants grown in a screen house as described earlier were used for this assay. The apical leaflets of leaves growing in the middle of plants near flowering stage were taken for inoculation. Prior to inoculation, leaflets were washed with sterilized distilled water and placed abaxial surface up in moist chambers, made of transparent plastic boxes $(20.3 \times 25.4 \times 12.7 \mathrm{~cm})$ containing two layers of water-soaked blotting papers at $1.5 \mathrm{~cm}$ below and $3.0 \mathrm{~cm}$ above the slices.

One $50 \mu \mathrm{l}$ drop of inoculum $\left(3 \times 10^{3}\right.$ sporangia $\left.\mathrm{ml}^{-1}\right)$ was placed on each leaflet using a micropipette. Sterile distilled water was applied on the check leaflets. Three leaflets per genotype were used as sub-samples. Inoculated leaflets were incubated at $16 \pm 0.5^{\circ} \mathrm{C}$ with $12 \mathrm{hr}$ light cycle. On the $7^{\text {th }}$ day after inoculation, the mean diameter of the lesion on each leaflet was measured as described by Nilsson (1981). The experiment was repeated twice.

\subsection{Tuber Slice Assay}

Three medium-sized, apparently healthy tubers of each of the 25 genotypes were washed with tap water, soaked in $2 \%$ sodium hypochlorite for $5 \mathrm{~min}$, rinsed with distilled water three times and air-dried. Five-mm-thick sections from the middle of each tuber were cut with a sterilized knife. One $50 \mu 1$ drop of inoculum with $3 \times 10^{3}$ sporangia $\mathrm{ml}^{-1}$, prepared as for the whole-plant assay, was placed at the center of each tuber slice. Four tuber slices per genotype were replicated thrice. Slices were placed in plastic boxes, lined with moist paper towels and incubated at $16 \pm 0.5^{\circ} \mathrm{C}$ with $12 \mathrm{hr}$ light cycle for 6 days. Percent area of tuber slice colonized by $P$. infestans was estimated by visual observation on the $6^{\text {th }}$ day. The experiment was done twice within 15 days under similar environmental conditions.

\subsection{Standardization of Resistance Measures}

An interval scale (0-9) as per Yuen and Forbes (2009) was used to standardize data from the field and the other assays as follows:

$$
\text { Standard scale }(0-9)=\frac{\text { Severity of test plant }}{\text { Severity of control }} \times 9.0
$$

Where 'severity' was the AUDPC for the field, percent foliage damage in whole-plant, mean lesion size $\left(\mathrm{cm}^{2}\right)$ for the detached leaf and percent area covered by colony for the tuber slice assay. The formula above is for a control which has an assigned severity value of 9 ; if the assigned value were different, the numbers in the formula would change accordingly. In cases where experiments were repeated, the average of experiments was used.

\section{Results}

\subsection{Field Assay}

Late blight severity observations in the field started from 30 DAP and continued up to 76 DAP when the susceptible check KufriJyoti had 100\% infection with an AUDPC of 2361 (Table 1). Many of the other genotypes were immune or had very little disease at the end of the evaluation period, with 16 of them having a susceptibility scale value of 1 or lower (Table 2). The susceptibility scale data from the field produced a clear bimodal frequency distribution indicating that many of the potato genotypes were probably incompatible with the local pathogen population (Figure 1). Several genotypes had values between 2 and 5 indicating moderate levels of resistance (Table 2). 
Table 1. Reaction of potato genotypes to Phytophthora infestans isolate (LPR-1) under field, screen house, detached leaves and tuber slices inoculated conditions at Khumaltar, Lalitpur in 2010

\begin{tabular}{|c|c|c|c|c|}
\hline Clones & $\begin{array}{l}\text { AUDPC in field } \\
\text { inoculation } \\
\text { assays }\end{array}$ & $\begin{array}{ll}\begin{array}{l}\text { Severity } \\
\text { screen }\end{array} & \text { under } \\
(\%) & \\
\end{array}$ & $\begin{array}{l}\text { Lesion size in } \\
\text { detached leaf } \\
\text { assay }\left(\mathrm{cm}^{2}\right)\end{array}$ & $\begin{array}{l}\text { Area covered } \\
\text { by colony }(\%)\end{array}$ \\
\hline PRP 35861.2 & 94 & 11.7 & 0.8 & 78.9 \\
\hline PRP-85861.12 & 93 & 18.3 & 1.2 & 4.4 \\
\hline PRP-25861.10 & 61 & 20.0 & 0.4 & 12.8 \\
\hline PRP-225861.2 & 120 & 43.3 & 0.7 & 66.1 \\
\hline LBr-40 (Resistant check) & 0 & 0.0 & 0.0 & 4.0 \\
\hline PRP-85861.8 & 77 & 35.0 & 3.6 & 15.9 \\
\hline L 235.4 & 916 & 60.0 & $\mathrm{DM}$ & 91.1 \\
\hline PRP-276264.01 & 26 & 5.0 & 2.5 & 65.0 \\
\hline PRP-266264.01 & 0 & 0.0 & 3.2 & 41.7 \\
\hline BSUPO3 & 27 & 5.0 & 4.7 & 96.1 \\
\hline KufriJyoti (Susceptible Check) & 2361 & 100.0 & 6.5 & 100.0 \\
\hline CIP-384321.15 & 28 & 5.0 & 0.7 & 23.3 \\
\hline PRP- 25861.1 & 39 & 18.3 & 1.9 & 12.6 \\
\hline CIP-388580.6 & 1054 & 50.0 & 4.8 & 22.8 \\
\hline CIP-394050.110 & 1287 & 58.3 & 4.7 & 20.8 \\
\hline CIP-393385.39 & 31 & 20.0 & 4.7 & 11.3 \\
\hline PRP-266264.15 & 0 & 11.2 & 4.8 & 25.0 \\
\hline Janakdev (CIP-720123) Check & 1153 & 70.0 & 5.5 & 36.4 \\
\hline CIP-393280.57 & 452 & 5.7 & 0.8 & 65.0 \\
\hline PRP-25861.11 & 103 & 11.7 & 0.4 & 9.4 \\
\hline PRP-85861.11 & 49 & 16.7 & 4.8 & 7.2 \\
\hline CIP-393077.54 & 713 & 26.7 & 4.8 & 78.3 \\
\hline CIP-392657.8 & 29 & 15.0 & 0.5 & 16.1 \\
\hline CIP-385499.11 & 1335 & 90.0 & 5.8 & 77.2 \\
\hline CIP-389746.2 & 692 & 46.0 & 4.2 & 67.8 \\
\hline$P$ value & $<.001$ & $<.001$ & $<.001$ & $<.001$ \\
\hline $\operatorname{LSD}(0.05)$ & 134.46 & 6.068 & 1.313 & 6.938 \\
\hline $\mathrm{CV} \%$ & 19.1 & 9.5 & 16.2 & 8.1 \\
\hline
\end{tabular}

DM: Data missing. 


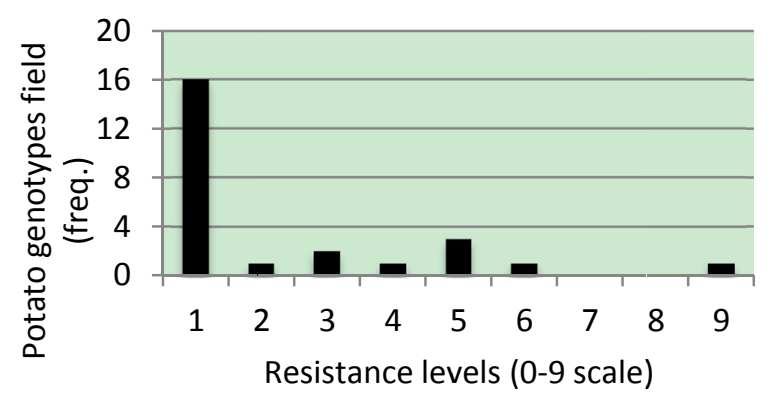

A

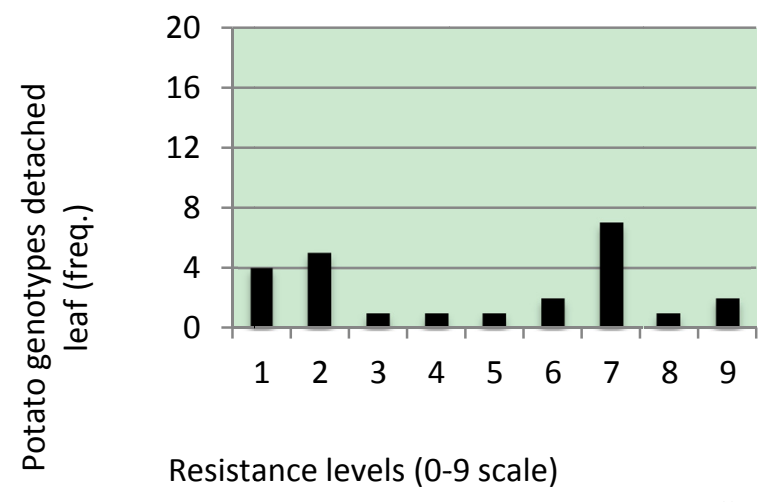

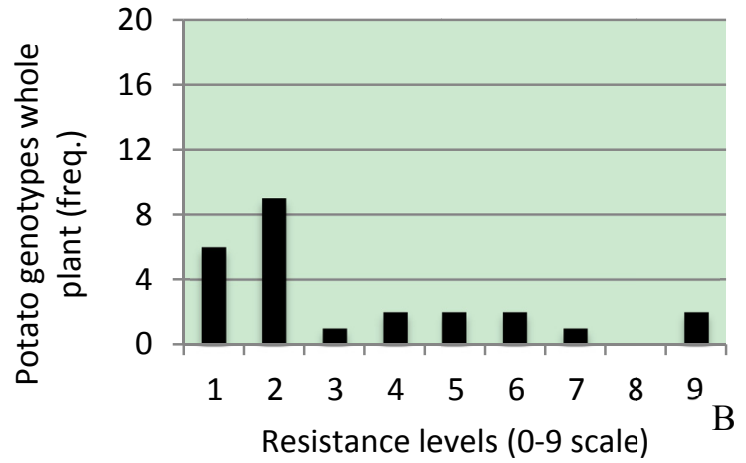

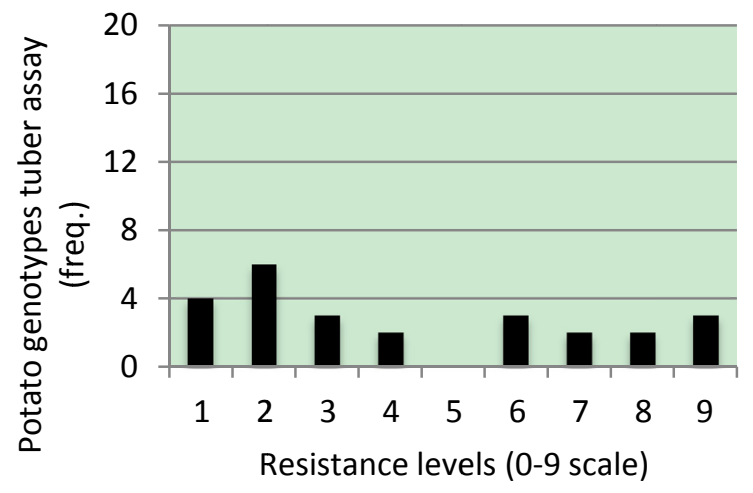

$\mathrm{C}$

$\mathrm{D}$

Figure 1. Frequency histogram of 25 potato genotypes evaluated for resistance levels against the late blight pathogen Phytophthora infestans in the field (A), on whole-plants in the screen house (B), by detached leaf inoculation (C) and by tuberslice inoculation (D) in Nepal

\subsection{Whole-Plant, Detached-Leaf and Tuber-Slice Assays}

Results of the whole plant, detached leaf and tuber slice assays were similar to field results in that a number of genotypes were extremely resistant or had even immune phenotypes (Table 1). However, the pattern differed among the assays; the three non-field assays all had fewer plants with a score of 1 or less (Table 2) and also had generally flatter distributions of scale values (Figure 1). Thus, some plants that were immune or nearly immune in the field became infected with the screen house and laboratory assays. Nonetheless, the resistant and susceptible checks were consistent in each assay (Table 1).

\subsection{Correlations among Assays}

All three assays (whole-plant, detached leaf and tuber slice) were significantly correlated with field data, although the highest correlation was with whole-plants $(r=0.90)$, followed by the detached leaf $(r=0.63)$ and finally the tuber assay $(\mathrm{r}=0.46)$ (Figure 2). The contrast among assays noted above could also be observed in this analysis; many plants with immune (or near-immune) reactions in the field had variable reactions in these assays. The lower correlation values are primarily an indication of the degree to which high levels of field resistance was not detected in the assays (Figure 2). 
Table 2. Scale values for resistance against Phytophthora infestans in 25 potato genotypes evaluated in the field, screen house, with detached leaves and tuber slices in Nepal in 2010

\begin{tabular}{|c|c|c|c|c|}
\hline \multirow{2}{*}{ Genotype } & \multicolumn{4}{|c|}{ Scale values } \\
\hline & Field & Whole-plant & Detached leaf & Tuber slice \\
\hline $\operatorname{LBr} 40$ ( C) & 0.0 & 0.0 & 0.0 & 0.4 \\
\hline PRP-266264.01 & 0.0 & 0.0 & $\underline{4.6}$ & $\underline{3.8}$ \\
\hline PRP-266264.15 & 0.0 & 1.0 & $\underline{6.8}$ & $\underline{2.3}$ \\
\hline PRP-276264.01 & 0.1 & 0.5 & $\underline{3.5}$ & $\underline{5.9}$ \\
\hline BSUPO3 & 0.1 & 0.5 & $\underline{6.7}$ & $\underline{8.7}$ \\
\hline CIP-392657.8 & 0.1 & $\underline{1.4}$ & 0.7 & $\underline{1.5}$ \\
\hline CIP-384321.15 & 0.1 & 0.5 & 1.0 & $\underline{2.1}$ \\
\hline PRP- 25861.1 & 0.1 & $\underline{1.7}$ & $\underline{2.6}$ & 1.1 \\
\hline CIP-393385.39 & 0.1 & $\underline{1.8}$ & $\underline{6.6}$ & 1.0 \\
\hline PRP-85861.11 & 0.2 & $\underline{1.5}$ & $\underline{6.8}$ & 0.7 \\
\hline PRP-25861.10 & 0.2 & $\underline{1.8}$ & 0.6 & 1.2 \\
\hline PRP-85861.8 & 0.3 & $\underline{3.2}$ & $\underline{5.0}$ & 1.4 \\
\hline PRP-85861.12 & 0.3 & $\underline{1.7}$ & $\underline{1.7}$ & 0.4 \\
\hline PRP-225861.2 & 0.3 & $\underline{3.9}$ & 1.0 & $\underline{6.0}$ \\
\hline PRP 35861.2 & 0.4 & 1.1 & 1.1 & $\underline{7.1}$ \\
\hline PRP-25861.11 & 0.4 & 1.1 & 0.6 & 0.9 \\
\hline CIP-393280.57 & 1.7 & 0.5 & 1.2 & 5.9 \\
\hline CIP-389746.2 & 2.6 & 4.1 & 6.0 & 6.1 \\
\hline CIP-393077.54 & 2.7 & 2.4 & 6.7 & 7.1 \\
\hline L 235.4 & 3.5 & 5.4 & DM & 8.2 \\
\hline CIP-388580.6 & 4.0 & 4.5 & 6.8 & 2.1 \\
\hline Janakdev( C) & 4.4 & 6.3 & 7.7 & 3.3 \\
\hline CIP-394050.110 & 4.9 & 5.3 & 6.6 & 1.9 \\
\hline CIP-385499.11 & 5.1 & 8.1 & 8.2 & 7.0 \\
\hline KufriJyoti( C) & 9.0 & 9.0 & 9.0 & 9.0 \\
\hline
\end{tabular}

C: Control variety, $\mathrm{DM}=$ Data missing.

Those values from whole-plants, detached leaves and tubers that are underlined had values of 2 or more (when values are rounded up), while having values of 1 or less in the field. 

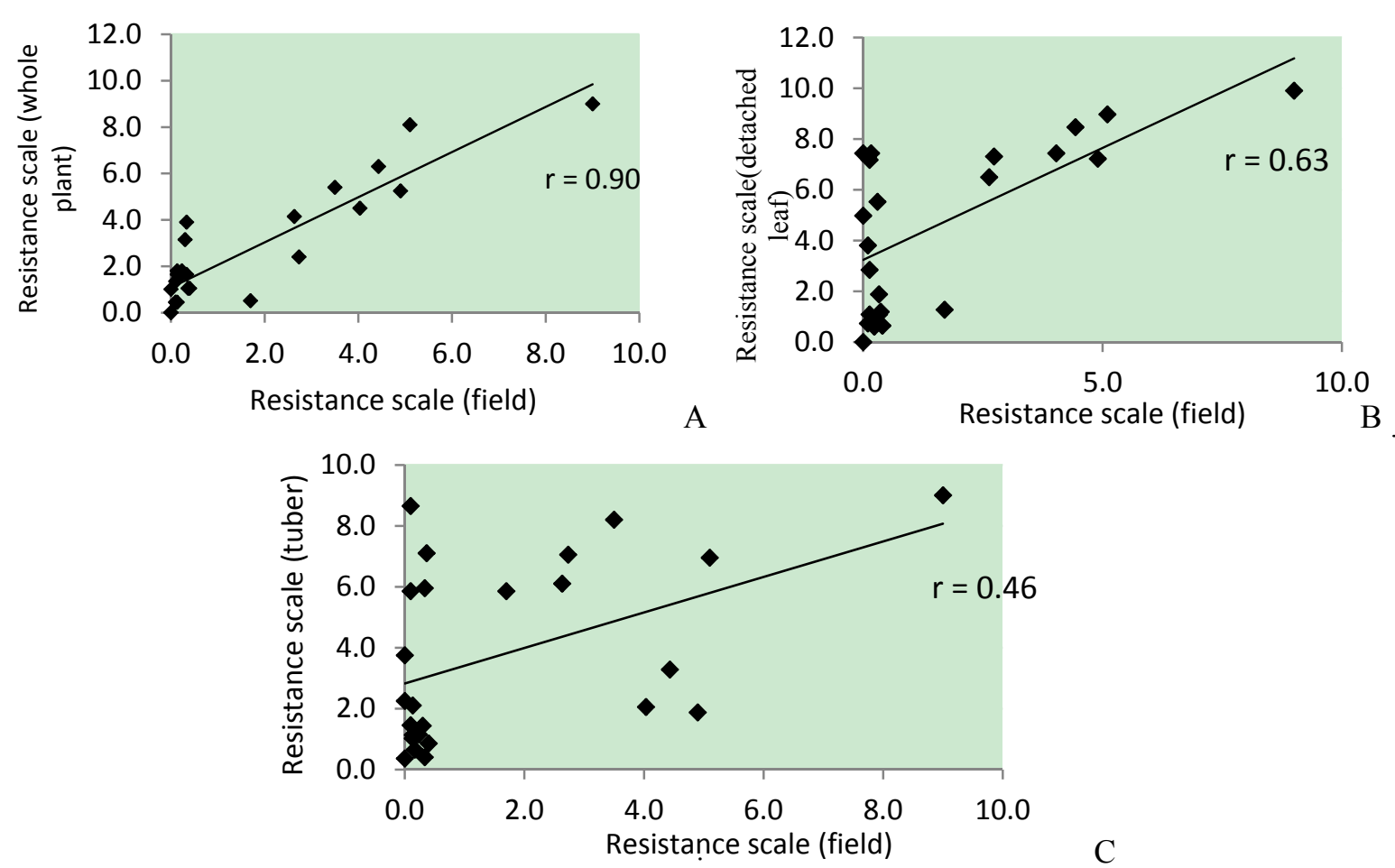

C

Figure 2. Resistance scale values in 25 potato genotypes against Phytophthora infestans as measured in the field correlated with resistance scale values measured in whole plants in a screen house (A), on detached leaves (B) and on tuber slices (C)

\section{Discussion}

This research demonstrated that several different assay tools can be used to evaluate genotypes of potato for their phenotypic reaction to $P$. infestans, and that in general, these assays will give results which are statistically correlated. Furthermore, the resistant and susceptible controls gave consistent results in all theassays. However, the study also demonstrated that while different tools generally give similar results, the results are not completely consistent and this should be taken into consideration.

Decades of research on potato late blight have demonstrated that highly resistant (immune or nearly immune) phenotypes can frequently indicate an active major $\mathrm{R}$ gene, for which compatibility in the pathogen population is absent or, more likely, extremely rare. If an incompatible potato genotype is released for use by farmers in most cases there will be selection of compatible pathogen population and a corresponding "loss" of resistance (Forbes, 2012). For this reason, some researchers have recommended selection of those phenotypes which demonstrate resistance, but are still infected (Forbes \& Landeo, 2006).

There were problems with the divergence in results from the resistance assays we tested which would make identification of a quantitative resistance phenotype difficult. In our test, the field evaluation of resistance indicated that 16 of the materials had little or no disease at the end of the season (Table 1). However, in the whole-plant (screenhouse) assay, eight of these 16 genotypes had values of 2 or greater on the resistance scale (when rounded up, Table 2) and thus one might assume that these materials have partial resistance, which could represent a high level of field or quantitative resistance. This also occurred with the detached leaf assay, where nine of the 16 highly resistant genotypes (from the field) had resistance scale values of 2 or more (Table 2); this apparent miss-identification of quantitative resistance in both the whole-plant and detached leaf assays did not always occur with the same genotypes (Table 2). Some genotypes from the 16 highly resistant clones in the field were also identified as partially resistant by the tuberslice test and a few were among the most susceptible, but tuber resistance and foliage resistance have been shown previously to be poorly correlated (Dorrance \& Inglis, 1997) and resistance in leaves and tubers may be governed by different genetic systems and/or reflect structural differences in the tissues. Some genotypes showing high level of resistance under field conditions were found most 
susceptible in tuber slice assay which also reflected genetic differences as foliage and tuber blight resistance are not always correlated.

Three major components are known to contribute to late blight resistance in tubers; 1 ) a physical barrier consisting of several layers of phloem cells, known the periderm; 2) the outer cortical cell layers that retard the growth of lesions and can completely block hyphal growth; and 3) medulla storage tissues which can reduce hyphal growth and sporulation of $P$. infestans (Flier,Turkensteen, \& Mulder, 1998; Flier, Turkensteen,Van den Bosch, Vereijken, \& Mulder, 2001; Pathak \& Clarke, 1987). Furthermore, immature tubers are more susceptible to tuber blight than mature tubers (Grinberger, Kadish, \& Cohen, 1995), which means that assayed tubers should be of similar age.

It is not possible to know at this time if all 16 genotypes found to have extremely high levels of resistance in the field do in fact indicate the presence of active major genes that would not be durable, but in at least one case we can assume this is the case based on previous experience. Genotype CIP- 393385.39, which had a resistance score of 0.1 in the field in Nepal, was also recently evaluated in Ethiopia where it was found to be highly susceptible (E. Schulte-Geldermann, personal communication). Thus, we assume that should CIP-393385.39 be adopted by farmers in Nepal, it would rapidly select for pathogenic strains in the pathogen population and the host resistance would become ineffective. Unfortunately, similar information is not available for the other 15 materials that were found to be extremely resistant.

Eight of the potato genotypes evaluated in the field had score value between 2 and 5 . It cannot be concluded that this resistance is of "horizontal" nature (effective against all pathotypes) but it would appear more probable that this resistance is durable, as we are aware of only a few cases when partial resistance has been clearly associated with short-lived R genes. One of the materials we evaluated, Janakdev, has been widely grown for years in Nepal and its moderate level of resistance appears to be stable. Thus, the remaining seven partially resistant genotypes are good candidates for further evaluation. Those genotypes which were extremely resistant should be considered as having an undetermined level of resistance until they can be confronted with compatible isolates; potato varieties that have "lost" $\mathrm{R}$ gene resistance frequently have a moderate level of residual resistance which is still useful.

The reasons of inconsistency between field values and those from the other assays are not known. It appears logical that a multi-cyclic test could give different results than mono- or oligocyclic tests for partial resistance, but this is not the case for extreme resistance. At this time, we do not know why some genotypes found to be extremely resistant in the field became infected in the detached leaf and whole-plant assays. It is possible that the stresses associated with the incubation methodology, or with cutting for the detached leaf test, created a situation highly favorable for the pathogen, unfavorable for the host, or both.

Our work would seem to be consistent with others (Dorrance \& Inglis, 1997; Douches et al., 2002) who claimed that screen house and laboratory assays cannot replace the value of evaluating germplasm for foliar resistance to late blight under field conditions. Whole-plant assays gave results relatively similar to the field, but one should be careful in the interpretation of results, particularly for those cultivars with apparently very high levels of quantitative resistance. Nonetheless, the whole-plant assay may serve to screen out highly susceptible potato genotypes.

\section{Acknowledgements}

The authors wish to thank the Nepal Agriculture Research Council (NARC), International Potato Center (CIP) and Republic of Austria, for funding to perform this important research in Nepal, under the project entitled "Ecological pest management on potato in Hindu-Kush Himalayan Region".

\section{References}

Black, W. (1970). The nature and inheritance of field resistance to late blight (Phytophthora infestans) in potatoes. American Potato Journal, 47, 279-288. http://dx.doi.org/10.1007/s10681-006-9320-3

Campbell, C. L., \& Madden, L. V. (1990). Introduction to Plant Disease Epidemiology. New York : John Wiley and Sons.

Dorrance, A. E., \& Inglis, D. A. (1997). Assessment of greenhouse and laboratory screening methods for evaluating potato foliage for resistance to late blight. Plant Disease, 81, 1206-1213. http://dx.doi.org/10.1094/PDIS.1997.81.10.1206

Douches, D. S., Kirk, W. W., Bertram, M. A., Coombs, J. J., \& Niemira, B. A. (2002). Foliar and tuber assessment of late blight (Phytophthora infestans (Mont.) de Bary reaction in cultivated potato (Solanum tuberosum L.). Potato Research, 45, 215-224. http://dx.doi.org/10.1007/BF02736116 
Flier, W. G., Turkensteen, L. J., \& Mulder, A. (1998). Variation in tuber pathogenicity of Phytophthora infestans in the Netherlands. Potato Research, 41, 345-354. http://dx.doi.org/10.1007/BF02358967

Flier, W. G., Turkensteen, L. J., Van den Bosch, G. B. M., Vereijken, P. F. G., \& Mulder, A. (2001). Differential interaction of Phytophthora infestans of potato cultivars with different levels of blight resistance. Plant Pathology, 50, 292-301. http://dx.doi.org/10.1046/j.1365-3059.2001.00574.x

Forbes, G. A. (2012). Using host resistance to manage potato late blight with particular reference to developing countries. Potato Research, 55, 205-216. http://dx.doi.org/10.1007/s11540-012-9222-9

Forbes, G. A., \& Landeo, J. A. (2006). Late Blight. In J. Gopal, \& P. KSM (Eds.), Handbook of Potato Production, Improvement, and Postharvest Management (pp. 279-314). Binghamton, NY: Haworth Press Inc.

Grinberger, M., Kadish, D., \& Cohen, Y. (1995). Infectivity of metalaxyl-sensitive and resistant isolates of Phytophthora infestans to whole potato tubers as affected by tuber aging and storage. Phytoparasitica, 23, $165-175$.

Haverkort, A., Struik, P., Visser, R., \& Jacobsen, E. (2009). Applied biotechnology to combat late blight in potato caused by Phytophthora infestans. Potato Research, 52, $249-264$. http://dx.doi.org/10.1007/s11540-009-9136-3

Inglis, D. A., Johnson, D. A., Legard, D. E., Fry, W. E., \& Hamm, P. B. (1996). Relative resistances of potato clones in response to new and old populations of Phytophthora infestans. Plant Disease, 80, 575-578. http://dx.doi.org/10.1094/PD-80-0575

Kamoun, S., Huitema, E., \& Vleeshouwers, V. G. A. A. (1999). Resistance to oomycetes: A general role for the hypersensitive response? Elsevier Trends Journals, 4, 196-200. http://dx.doi.org/10.1016/S1360-1385(99)01404-1

Kirk, W. W., Felcher, K. J., Douches, D. S., Niemira, B. A., \& Hammerschmidt, R. (2001). Susceptibility of potato (Solanum tuberosum L.) foliage and tubers to the US-8 genotype of Phytophthora infestans. American Journal of Potato Research, 78, 319-322. http://dx.doi.org/10.1007/BF02875697

Kromann, P., Taipe, A., Perez, W., \& Forbes, G. (2009). Rainfall thresholds as support for timing fungicide applications in the control of potato late blight in Ecuador and Peru. Plant Disease, 93, 142-148. http://dx.doi.org/10.1094/PDIS-93-2-0142

Madden, L. V., \& Hughes, G. (1995). Plant disease incidence: distributions, heterogeneity, and temporal analysis. Annual Review of Phytopathology, 33, 529-564. http://dx.doi.org/10.1146/annurev.py.33.090195.002525

MOAC. (2011). Statistical Information on Nepalese Agriculture. Ministry of Agriculture and Cooperatives, Agribusiness Promotion and Statistics Division, Singh Durbar, Kathmandu, Nepal.

MOF. (2010). Economic Survey 2009/10. Ministry of Finance Government of Nepal.

Nilsson, B. A. (1981). Component analysis of general resistance to Phytophthora infestans in clones from the Colombian potato collection. Potato Research, 24, 239-244. http://dx.doi.org/10.1007/BF02360361

Pathak, N., \& Clarke, D. D. (1987). Studies on the resistance of the outer cortical tissues of the tubers of some potato cultivars to Phytophthora infestans. Physiological and Molecular Plant Pathology, 31, $123-132$. http://dx.doi.org/10.1016/0885-5765(87)90011-7

Platt, H. W., \& Tai, G. (1998). Relationship between resistance to late blight in potato foliage and tubers of cultivars and breeding selections with different resistance levels. American J. Potato Research, 75, $173-178$. http://dx.doi.org/10.1007/BF02853569

Sharma, B. P., Khatri-Chhetri, R. B. , Dhital, S. P., Khatri-Chhetri, H. B., \& Chand, G. B. (2007). Farmers empowerment and adoption of potato disease management technology through farmers' field school and participatory research. Proceedings of the $8^{\text {th }}$ National Outreach Research Workshop, 19-20 June, NARC, Nepal.

Tan, M. Y. A., Hutten, R. C. B., Visser, R. G. F., \& Eck, H. J. (2010). The effect of pyramiding Phytophthora infestans resistance genes R Pi-mcd1 and R Pi-ber in potato. Theoretical and Applied Genetics, 121, 117-125. http://dx.doi.org/10.1007/s00122-010-1295-8

Van der Plank, J. E. (1963). Plant Diseases: Epidemics and Control. New York, London: Academic Press. 
Vleeshouwers, V. G. A. A., Raffaele, S., Vossen, J., Champouret, N., Oliva, R., Segretin, M.E., \& Kamoun, S. (2011). Understanding and exploiting late blight resistance in the age of effectors. Annual Review of Phytopathology, 49, 507-531. http://dx.doi.org/10.1146/annurev-phyto-072910-095326

Yuen, J. E., \& Forbes, G. A. (2009). Estimating the level of susceptibility to Phytophthora infestans in potato genotypes. Phytopathology, 99, 782-786. http://dx.doi.org/10.1094/PHYTO-99-6-0782 